\title{
Michal Staszków
}

Uniwersytet Ekonomiczny w Poznaniu

e-mail: michal.staszkow@ue.poznan.pl

\section{ZNACZENIE FAZY ROZWOJU \\ W OCENIE EFEKTYWNOŚCI \\ PARKU TECHNOLOGICZNEGO \\ IMPORTANCE OF DEVELOPMENT PHASE \\ IN THE ASSESSMENT \\ OF TECHNOLOGY PARK PERFORMANCE}

DOI: $10.15611 /$ pn.2017.499.25

JEL Classification: O32, $\mathrm{O} 33$

Streszczenie: Parki naukowo-technologiczne są obiektem badań od lat 50. XX wieku, kiedy to powstał pierwszy podmiot tego typu. Liczba parków technologicznych na świecie stopniowo wzrastała, a w Europie, dzięki dostępności funduszy unijnych, można było zauważyć prawdziwy boom na budowę parków na początku XXI wieku. W literaturze przedmiotu wymienia się trzy generacje parków technologicznych, a także różne modele zarządzania instytucjami tego typu. Niezależnie od tego, czy park funkcjonuje jako uniwersytecki, partnerski, grupowy, w modelu zintegrowanym, hybrydowym czy rozproszonym, przechodzi przez określone stadia rozwoju - od pomysłu, aż po dojrzałość organizacyjną i zarządczą. Celem artykułu jest ocena znaczenia faz rozwoju instytucji tego typu na sposób oceny efektywności.

Słowa kluczowe: park technologiczny, innowacje, pomiar efektywności.

Summary: Science and technology parks have been the subject of research since the 1950s, when the first entity of its kind was established. The number of technology parks in the world has gradually increased, and in Europe, due to the availability of EU funds, there was a real boom for the construction of parks at the beginning of the 21 st century. The literature on the subject lists three generations of technology parks, as well as various models of management of such institutions. Whether the park operates as a university, partnership, group, integrated or hybrid model, it goes through specific phases of development - from the concept to organizational and managerial maturity. The purpose of this article is to evaluate the importance of the development phases in such entities and how it influences the performance assesment.

Keywords: technology park, innovation, measurement of effectiveness. 


\section{Wstęp}

Parki technologiczne, szczególnie w ostatnich latach, traktowane są jako narzędzie, które wspierać ma realizację założeń polityki innowacyjnej w wielu krajach świata. Analiza teoretycznych podstaw funkcjonowania jednostek tego typu zdaje się potwierdzać to założenie. Firmy wchodzące w skład parków technologicznych (czy też będące ich lokatorami) z założenia powinny być firmami innowacyjnymi, a ich zlokalizowanie w jednym miejscu umożliwia nawiązywanie współpracy, ułatwia przepływ wiedzy, a przez to także kreuje środowisko proinnowacyjne. Te cechy parków naukowo-technologicznych powodują, że efekty ich działalności zauważane są głównie na poziomie regionalnym, dlatego tego typu jednostki często tworzone są przez samorządy lokalne bądź uczelnie wyższe.

W literaturze przedmiotu funkcjonuje wiele nazw odnoszących się do koncepcji parku technologicznego: parki naukowe, technologiczne, badawcze, naukowo-badawcze, naukowo-technologiczne, przemysłowe, przemysłowo-technologiczne [Link, Scott 2007; Pelle, Bober, Lis 2008; Link 2009; The World Bank 2010; Matusiak 2011].

Różnice w nazewnictwie parków wynikają z uwarunkowań kulturowych, prawnych, a także własnościowych. W Polsce najczęściej stosowaną nazwą jest „park technologiczny”, we Francji technopolis, a w Stanach Zjednoczonych ,park badawczy", co wiąże się z funkcjonowaniem parków w ramach uczelni wyższej bądź w jej bezpośredniej okolicy. Pełnione funkcje są jednak zbieżne bądź bardzo zbliżone i skupiają się na wspieraniu innowacyjności i przedsiębiorczości.

Analogicznie do koncepcji cyklu życia produktów parki technologiczne przechodzą podobne stadia - od koncepcji, przez wdrożenie, po dojrzałość i schyłek funkcjonowania. Artykuł ma być odpowiedzią na pytanie: jakie elementy są kluczowe w poszczególnych fazach rozwoju parku technologicznego oraz jakie mierniki stosować, aby ocena ta była adekwatna do danej fazy rozwoju? Wnioski i wyniki przedstawione w niniejszym opracowaniu są efektem przeprowadzonych badań empirycznych. Badaniem objęte zostały 42 parki technologiczne z Polski zidentyfikowane na podstawie raportu SOOIPP [Bąkowski, Mażewska 2015] oraz strony internetowej tej organizacji. Na badanie odpowiedziało 30 parków, zatem wskaźnik zwrotu wyniósł $71 \%$. Kolejną badaną grupą były parki technologiczne ze Stanów Zjednoczonych, które uznawane są za najlepiej rozwinięte jednostki tego typu na świecie. W celu identyfikacji parków technologicznych w Stanach Zjednoczonych autor posłużył się bazą organizacji Association of University Research Parks zamieszczoną na stronie internetowej [AURP 2015]. Z 71 wysłanych ankiet uzyskano odpowiedzi z 17 jednostek, wskaźnik zwrotu wyniósł 24\%. 


\section{Ewolucja koncepcji parków technologicznych}

W literaturze przedmiotu wymienia się trzy generacje parków technologicznych. Parki pierwszej generacji powstały w latach 1950-1980, a ich celem było wsparcie procesu reindustrializacji i rozwój przemysłu. Takie cele, jak transfer wiedzy czy też kreowanie produktów innowacyjnych, które dziś stanowią fundament funkcjonowania parków, traktowane były jako korzystny, acz mało istotny efekt funkcjonowania lokatorów parków [Staszków 2013]. Parki pierwszej generacji powoływane były przede wszystkim przez uczelnie wyższe, które chciały zarobić na niewykorzystywanych powierzchniach uniwersyteckich budynków. Wraz z upływem lat oferta wynajmu powierzchni dopasowywana była do oczekiwań nowych firm, które nie podlegały już procesowi reindustrializacji. Sukces tego typu działań spowodował, że uniwersytety nastawiły się na bardziej komercyjne wykorzystanie badań naukowych, realizowanych często we współpracy z lokatorami parków technologicznych.

Sukcesy pierwszych parków zostały zauważone przez władze publiczne, które zaczęły traktować tego typu instytucje jako narzędzia polityki innowacyjnej, co doprowadziło do stworzenia parków drugiej generacji, głównie w latach 90 . XX wieku. Parki naukowo-technologiczne drugiej generacji, obok funkcji infrastrukturalnej, oferują wachlarz usług okołobiznesowych, które ułatwiają rozwój firm innowacyjnych z określonych branż, m.in. IT, biotechnologii, medycyny. Skupienie na branży wynikało początkowo ze specjalizacji uczelni, jednak z czasem politycy, uznając pewne branże za bardziej przyszłościowe i dochodowe, decydowali o tworzeniu parków ze specjalizacją z góry określoną, również poza uniwersytetami [Henneberry 1984]. Jest to jeden z charakterystycznych punktów w ewolucji koncepcji parków - znaczenie uniwersytetów jako podmiotów powołujących i koordynujących parki technologiczne zmniejszyło się. Sama specjalizacja działalności parku daje wiele korzyści, np. wspomnianą koncentrację firm z danej branży w jednym miejscu, co ułatwia przepływ wiedzy i umożliwia współpracę. Kolejnym plusem jest dostosowanie oferty parku do potrzeb konkretnej grupy klientów. Inną cechą charakterystyczną parków drugiej generacji była ich funkcja inkubacyjna. Starano się umożliwić studentom i absolwentom rozwój firm poprzez wsparcie finansowe i zarządcze, co w początkowej fazie działalności gospodarczej jest kluczowe.

W koncepcji parków trzeciej generacji podkreśla się fakt, że mają one być narzędziem, które umożliwi wzrost poziomu innowacyjności i konkurencyjności gospodarki. Działalność inkubacyjna została uzupełniona o funkcję kreatora sieci powiązań - funkcję networkingową. Parki drugiej generacji, w związku z intensywnym rozwojem komercyjnych jednostek tego typu, odsunęły na dalszy plan uniwersytety. W parkach trzeciej generacji ponownie mocno podkreśla się rolę uczelni wyższych w kreowaniu wiedzy i innowacji, a budowanie relacji między lokatorami parku i uczelniami ma być jednym z najważniejszych zadań stojących przed parkami. Uważane są one również za miejsce, gdzie nauka łączy się z biznesem, a studenci i naukowcy mogą realizować swoje pomysły dzięki z jednej strony wsparciu i do- 
świadczeniu uczelni, a z drugiej dzięki kapitałowi prywatnych przedsiębiorców zlokalizowanych na terenie parku.

Aktualnie parki, zarówno te dojrzałe, jak i w początkowej fazie rozwoju, z założenia uznawane są za parki trzeciej generacji. Wynika to przede wszystkim z funkcji, do pełnienia których zostały powołane, a także z założeń polityki innowacyjnej, której są częścią. W niniejszej pracy opisywane aspekty również dotyczą parków trzeciej generacji.

\section{Fazy rozwoju parków technologicznych}

Niezależnie od nazewnictwa czy określonej specjalizacji park technologiczny przechodzi przez określone stadia rozwoju - od pomysłu, aż po dojrzałość organizacyjną i zarządczą. Bank Światowy [World Bank 2010] określił działania, które powinny zostać podjęte w ramach tworzenia i zarządzania parkiem technologicznym; są to:

- Ustalenie strategii - określana jest ona na poziomie lokalnym. Obejmuje określenie celów, ewentualnej specjalizacji parku i usług świadczonych na rzecz lokatorów.

- Planowanie - planowanie infrastruktury, struktury organizacyjnej i budżetu operacyjnego.

- Działanie - fizyczna budowa i pierwsze rozmowy z potencjalnymi lokatorami parku.

- Komercjalizacja i promocja - wynajem powierzchni lokatorom, określenie spójnej strategii promocji, w dalszym okresie możliwa jest rozbudowa zarówno zakresu usług, jak i samej infrastruktury.

- Ocena efektywności - ocena powinna odbywać się w odniesieniu do każdego z wyżej wymienionych działań. Należy dostosować mierniki do poszczególnych faz rozwoju, aby w efekcie móc porównać parki znajdujące się w danej fazie rozwoju. Parki, prowadząc ocenę efektywności we własnym zakresie, mogą również ocenić, czy udało im się osiągnąć zakładane cele.

Mając na uwadze metodykę prowadzenia badań oraz ograniczenia związane z pozyskiwaniem odpowiedzi w przypadku zbyt rozbudowanych kwestionariuszy, autor niniejszego artykułu ograniczył liczbę faz rozwoju, a jednocześnie zawarł w nich takie elementy, które będą uniwersalne dla parków w Polsce i w Stanach Zjednoczonych. Na potrzeby artykułu przyjął definicję profesora Johna Allena, wieloletniego dyrektora Manchester Science Park oraz dwukrotnego prezesa UKSPA, wyróżniającego trzy fazy rozwoju, takie jak:

- Faza początkowa - trwa zazwyczaj kilka lat, obejmuje etap planowania, tworzenia koncepcji oraz zawarcie porozumienia między udziałowcami parku co do jego powstania, finansowania i bieżącej działalności.

- Faza wzrostu - obejmuje rozwój oferty parku, zarówno w kwestii powstającej powierzchni biurowej, jak i usług dla potencjalnych lokatorów. W tej fazie zarządzanie i działania operacyjne mają kluczowe znaczenie i stają się bardziej 
efektywne. Część parków pozostaje na dłużej w fazie spokojnego wzrostu i stabilnego zarządzania.

- Faza dojrzałości - oznacza zmianę w kierunku indywidualnego stylu zarządzania parkiem, który odróżnia go od innych podmiotów na rynku. Park może pochwalić się znaczącymi wynikami działalności, przyczyniającymi się do rozwoju innowacyjności [Allen 2007].

Badaniem, oprócz wspomnianych osób zarządzających parkami w Polsce oraz w Stanach Zjednoczonych, objęta została grupa 18 ekspertów (przedstawiciele nauki, wieloletni menedżerowie parków technologicznych, dyrektorzy organizacji zrzeszających parki technologiczne na świecie) z wielu krajów, m.in. Wielkiej Brytanii, Szwecji, Niemiec, Estonii, Stanów Zjednoczonych, Japonii, Chin. Grupa ta stanowiła grupę kontrolną. Reprezentanci parków technologicznych poproszeni zostali o określenie, w odniesieniu do wyżej przyjętej definicji faz rozwoju, w której fazie rozwoju znajduje się ich instytucja. Zgodnie z wynikami przedstawionymi w tab. 1, większość parków w Polsce znajduje się w fazie rozwoju, podczas gdy parki w Stanach Zjednoczonych reprezentują w równym stopniu fazy rozwoju oraz dojrzałości.

Tabela 1. Badane parki technologiczne w poszczególnych fazach rozwoju

\begin{tabular}{|l|c|c|c|c|}
\hline \multirow{2}{*}{$\begin{array}{c}\text { Fazy } \\
\text { rozwoju }\end{array}$} & \multicolumn{2}{|c|}{$\begin{array}{c}\text { Polska } \\
(n=29)\end{array}$} & \multicolumn{2}{c|}{$\begin{array}{c}\text { USA } \\
(n=17)\end{array}$} \\
\cline { 2 - 5 } & $\begin{array}{c}\text { udział } \\
\text { procentowy }\end{array}$ & $\begin{array}{c}\text { liczba } \\
\text { wskazań }\end{array}$ & $\begin{array}{c}\text { udział } \\
\text { procentowy }\end{array}$ & $\begin{array}{c}\text { liczba } \\
\text { wskazań }\end{array}$ \\
\hline Faza początkowa & 27,0 & 8 & 5,9 & 1 \\
\hline Faza wzrostu & 58,6 & 17 & 52,9 & 9 \\
\hline Faza dojrzałości & 13,8 & 4 & 41,2 & 7 \\
\hline
\end{tabular}

Źródło: opracowanie własne.

Parki technologiczne w Polsce reprezentują wszystkie trzy fazy rozwoju, a jednocześnie żaden z nich nie działa na rynku tak długo, aby w badaniach empirycznych trzeba było brać pod uwagę fazę schyłkową, została ona jednak uwzględniona w zaproponowanym modelu koncepcyjnym (rys. 1). Ze względu na ograniczenia objętościowe artykułu autor zdecydował się jedynie na opisanie metodyki prowadzenia badań oraz zamieszczenie ilustracji obrazującej finalny efekt pracy, wskazujący, jakie mierniki efektywności są najistotniejsze w odniesieniu do poszczególnych faz rozwoju parku, a także określający działania, które są kluczowe w funkcjonowaniu parków technologicznych w poszczególnych fazach rozwoju.

Analizując narzędzia służące do badania efektywności parków technologicznych, a także na podstawie badań literaturowych, autor stworzył autorski zestaw mierników, który poddany został badaniom (tab. 2). Tworząc kwestionariusz, opierał się na koncepcji strategicznej karty wyników, dokonując jednocześnie pewnych mo- 
dyfikacji. Zastąpił perspektywę procesów wewnętrznych perspektywą interesariuszy, w której znalazły się mierniki oceniające również bieżące funkcjonowanie parku. Perspektywa klientów określona została jako perspektywa lokatorów. Zmiany te wynikały z chęci jak najlepszego dopasowania mierników do specyfiki funkcjonowania parków technologicznych. Po przeprowadzeniu badania pilotażowego autor artykułu zdecydował się na ograniczenie liczby mierników do 8 w każdym z czterech obszarów. Mierniki zakwalifikowane do ostatecznego badania przedstawia tab. 2.

Tabela 2. Mierniki efektywności zakwalifikowane do dalszego badania

\begin{tabular}{|c|c|}
\hline Perspektywa finansowa & Perspektywa udziałowców \\
\hline $\begin{array}{l}\text { 1. Koszt budowy parku } \\
\text { 2. Wydatki inwestycyjne } \\
\text { 3. Przychody z tytułu wynajmu powierzchni } \\
\text { 4. Wartość pozyskanych środków publicznych } \\
\text { 5. Wartość środków pozyskanych z Unii } \\
\text { Europejskiej (lub jako granty z innych } \\
\text { organizacji międzynarodowych) } \\
\text { 6. Przychody ogółem } \\
\text { 7. Zysk brutto } \\
\text { 8. Wewnętrzna stopa zwrotu (IRR) }\end{array}$ & $\begin{array}{l}\text { 1. Wydatki parku na marketing } \\
\text { 2. Liczba pracowników parku (jednostki } \\
\text { zarządzającej) } \\
\text { 3. Nowi klienci (w danym roku) } \\
\text { 4. Liczba nowych lokatorów w parku w okresie } \\
\text { ostatnich } 12 \text { miesięcy } \\
\text { 5. Liczba lokatorów, którzy opuścili park, } \\
\text { a dalej prowadzą działalność } \\
\text { 6. Liczba współpracujących przedsiębiorstw } \\
\text { 7. Liczba projektów realizowanych przez park } \\
\text { technologiczny w partnerstwie z innymi } \\
\text { instytucjami } \\
\text { 8. Nowe miejsca pracy w firmach (lokatorach) }\end{array}$ \\
\hline Perspektywa lokatorów & Perspektywa rozwoju \\
\hline $\begin{array}{l}\text { 1. Udział lokatorów w wydarzeniach } \\
\text { networkingowych } \\
\text { 2. Procent firm inkubowanych, które po tej fazie } \\
\text { pozostały w parku } \\
\text { 3. Liczba nowych produktów lub usług } \\
\text { stworzonych przez lokatorów } \\
\text { 4. Liczba otrzymanych patentów przez lokatorów } \\
\text { 5. Liczba udzielonych przez lokatorów licencji } \\
\text { 6. Firmy inwestujące w B+R } \\
\text { 7. Wartość inwestycji w B+R } \\
\text { 8. Liczba zatrudnionych osób, ze stopniem doktora } \\
\text { lub wyżej }\end{array}$ & $\begin{array}{l}\text { 1. Czas budowy parku (w miesiącach) } \\
\text { 2. Powierzchnia parku (ha) } \\
\text { 3. Powierzchnia budynków parku }\left(\mathrm{m}^{2}\right) \\
\text { 4. Liczba lokatorów } \\
\text { 5. Liczba firm typu start-up/spin-off } \\
\text { 6. Poziom wykorzystania (wynajmu) } \\
\text { powierzchni budynków parku } \\
\text { 7. Liczba oferowanych usług przez park } \\
\text { 8. Rotacja pracowników w ciągu ostatnich } 3 \text { lat }\end{array}$ \\
\hline
\end{tabular}

Źródło: opracowanie własne.

Badanie miało na celu sprawdzenie, czy osoby zarządzające parkami technologicznymi w Polsce, w Stanach Zjednoczonych i eksperci różnią się pod względem oceny wybranych mierników efektywności parków technologicznych w poszczególnych fazach rozwoju. Analiza przeprowadzona została z użyciem testu wariancji Kruskala-Wallisa, który jest rozszerzeniem testu U Manna-Whitneya. W celu spraw- 
dzenia istotności różnic oceny poziomu ważności wybranych mierników pomiędzy poszczególnymi fazami rozwoju, w podziale na osoby zarządzające parkami technologicznymi w Polsce, w Stanach Zjednoczonych i ekspertów, zastosowano test Wilcoxona. Przedstawiony na rys. 1 schemat prezentujący poszczególne fazy rozwoju, a także działania podejmowane w poszczególnych fazach jest graficzną syntezą wniosków płynących z wymienionych analiz, które były zbyt obszerne, aby zamieszczać je w niniejszym artykule.

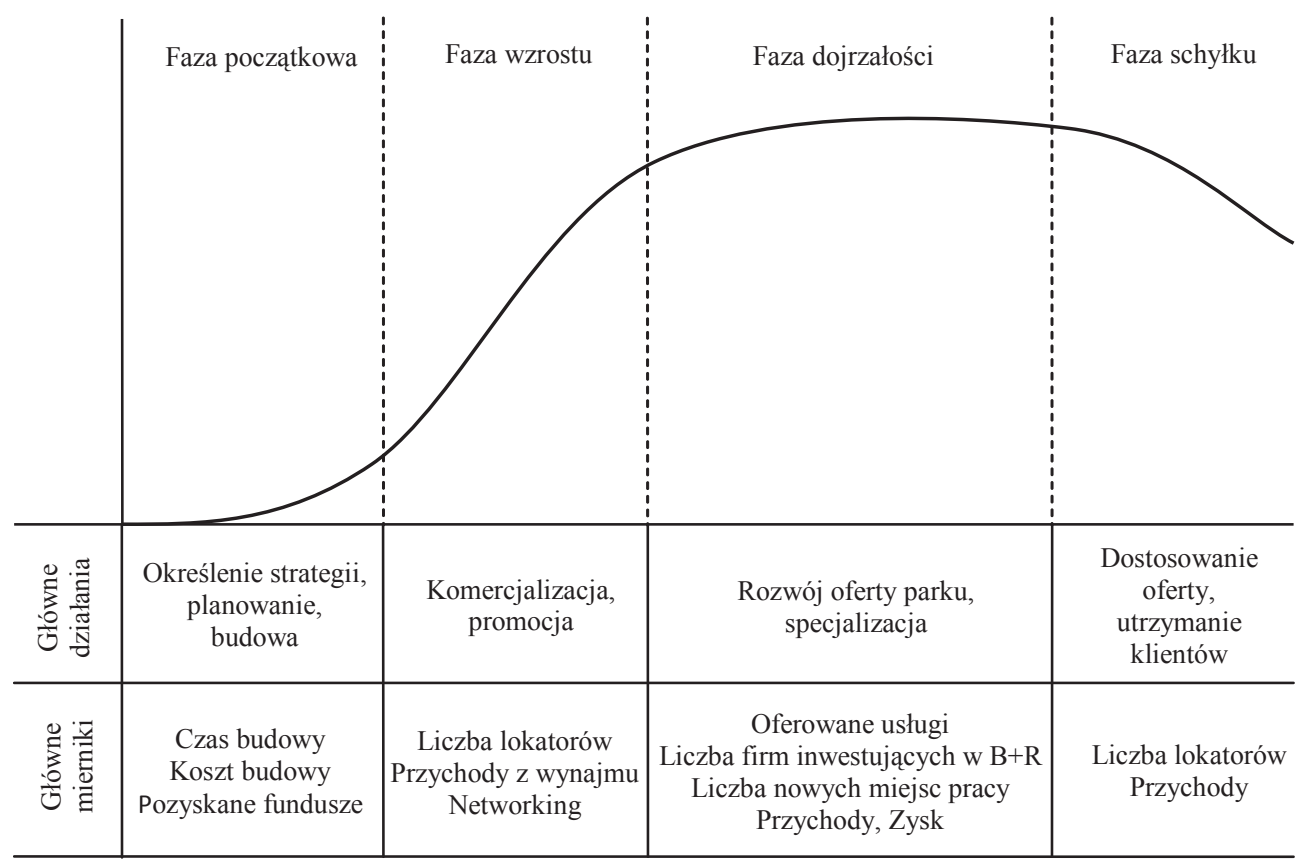

Rys. 1. Fazy rozwoju a działalność parku i mierniki efektywności

Źródło: opracowanie własne.

W fazie początkowej najistotniejsze wydają się ustalenie strategii oraz kwestia fizycznej budowy parku technologicznego. Wiąże się z tym pozyskanie funduszy na budowę i funkcjonowanie, zatem najważniejszymi miernikami w fazie początkowej jest czas budowy, koszt budowy oraz ilość pozyskanych funduszy. W fazie wzrostu park zaczyna komercjalizację powierzchni biurowej i laboratoryjnej, dlatego istotne są działania promocyjne. Ważnymi miernikami w tej fazie są liczba lokatorów, przychody z wynajmu, które powinny równoważyć budżet, a także działania networkingowe, które budują atmosferę proinnowacyjną wśród lokatorów.

W fazie dojrzałości park powinien mieć już ugruntowaną pozycję na rynku, dlatego działania skupiają się na zapewnieniu wysokiej jakości usług dla lokatorów. W tej fazie efektywnie działający park może pochwalić się realnym wpływem na 
innowacyjność regionu, dlatego istotnymi miernikami są liczba firm inwestujących w $\mathrm{B}+\mathrm{R}$, liczba nowych miejsc pracy, a także (z biznesowego punktu widzenia) przychody i zyski, które pozwalają na dalszy rozwój oferty parku.

W fazie schyłku infrastruktura techniczna może nie spełniać wymagań lokatorów i ci mogą chcieć opuścić park na rzecz innego podmiotu bądź własnej siedziby. Najistotniejszym działaniem jest zatem utrzymanie dotychczasowych klientów [Staszków 2016] i dostosowanie oferty parku do ich potrzeb. Kluczowym miernikiem ponownie jest liczba lokatorów, a także przychody, które w tej fazie mogą zacząć spadać.

\section{Zakończenie}

Parki technologiczne są podmiotami zróżnicowanymi zarówno pod względem wie$\mathrm{ku}$, jak i struktury własnościowej, a ich nazewnictwo zmienia się w zależności od kraju, w którym funkcjonują. Poszczególne cele zależą również od tego, w jakiej fazie rozwoju znajduje się dana jednostka. Na podstawie przeprowadzonych analiz można stwierdzić, że w fazie początkowej najistotniejszą kwestią jest pozyskiwanie funduszy oraz czas i koszt budowy parku. Dopiero w dalszym etapie, w fazie wzrostu i dojrzałości, na znaczeniu zyskują cele polityczne - rozwój i inkubacja nowych firm czy też tworzenie miejsc pracy.

Przykłady parków w Stanach Zjednoczonych pokazują, że są one w stanie osiągać stawiane przed nimi cele statutowe. Za główne źródło sukcesu uznaje się duże zaangażowanie uczelni wyższych w rozwój i zarządzanie parkami, co w przypadku polskich jednostek nie jest regułą. Publiczny charakter amerykańskich parków sprawia, że kwestia zysku wydaje się mniej ważna dla osób zarządzających parkiem. Wyniki badań wskazują, że głównym celem staje się realizacja założeń o charakterze polityczno-społecznym. Polskie parki cechuje zróżnicowana struktura własnościowa, jednak ich cele powinny być spójne z regionalną polityką innowacyjną, warto zatem skupić się na budowaniu relacji i sieci powiązań parku w ramach wszystkich jego interesariuszy, w tym regionalnego systemu innowacji, jednostkami naukowymi, niezależnymi ekspertami i instytucjami finansowymi. Jeśli chodzi o finanse, to polskie jednostki, w przeciwieństwie do ich amerykańskich odpowiedników, kładą duży nacisk na finansowanie ze środków samorządowych czy unijnych, jednak w dłuższej perspektywie konieczne jest równoważenie budżetu wpływami z innych źródeł, najczęściej z wynajmu powierzchni. Elementem, do którego dużą wagę przywiązują menedżerowie amerykańskich parków, jest profil branżowy lokatorów; jest to również aspekt, na który należy zwrócić uwagę w polskich parkach. Aby jednak przyciągnąć lokatorów o odpowiednim profilu, trzeba zwiększyć liczbę faktycznie świadczonych usług proinnowacyjnych. Powinny być one świadczone nie tylko dla lokatorów, lecz również dla klientów zewnętrznych, co pozwoli na zdywersyfikowanie budżetu. Menedżerowie amerykańskich parków oraz naukowcy podkreślają znaczenie określenia strategii $\mathrm{w}$ rozwoju parku technologicznego, a także doboru 
kadry zarządzającej, która będzie rozumiała specyficzną funkcję oraz cele stawiane parkom technologicznym.

Prowadzone badania obarczone są pewnymi ograniczeniami. Pierwsze z nich, związane z metodyką prowadzenia badań, dotyczy zawężenia analizy do trzech faz rozwoju, pomijając fazę schyłku. Ograniczenie to pozwoliło w znaczącym stopniu skrócić kwestionariusz ankiety. Mimo to uzyskana liczba odpowiedzi ze Stanów Zjednoczonych nie jest satysfakcjonująca, co również uznać można za ograniczenie badania. Badania prowadzone w kolejnych latach będą musiały uwzględniać fazę schyłkową. Warto również rozszerzyć badania o inne kraje.

Przeprowadzona analiza i wyniki badań empirycznych wskazują na konieczność kontynuacji w przyszłości badań dotyczących działalności parków naukowo-technologicznych. Zarówno z punktu widzenia poznawczego, jak i praktycznego ciekawe może okazać się badanie porównawcze celów statutowych, deklaratywnych, wynikających z definicji parku technologicznego, z celami faktycznie realizowanymi przez parki charakteryzujące się różną strukturą własnościową. Praktycznym problemem badawczym, na który zwracają uwagę lokatorzy parków, jest analiza zapotrzebowania lokatorów na usługi oferowane przez parki technologiczne, a także badanie satysfakcji klientów z dotychczas świadczonych usług.

\section{Literatura}

Allen J., 2007, Third Generation Science Parks, Manchester Science Park.

AURP, Association of University Research Parks, http://www.aurp.net/sustaining-park-members (dostęp 8.02.2016).

Bąkowski A., Mażewska M., 2015, Ośrodki innowacji i przedsiębiorczości w Polsce. Raport 2014, Stowarzyszenie Organizatorów Ośrodków Innowacji i Przedsiębiorczości w Polsce, Warszawa/ Poznań.

Henneberry J.M., 1984, British and American Science Parks: A comparison, Property Management, vol. 2 , iss. 4 , s. 301-313.

Link A.N., 2009, Research, Science and Technology Parks: An Overview of the Academic Literature, [w: ] Ch.W. Wessner (red.), Understanding Research, Science and Technology Parks: Global Best Practice, Report of a Symposium, National Research Council, National Academy of Sciences, The National Academies Press, Washington D.C.

Link A.N., Scott J.T., 2007, The economics of university research parks, Oxford Review of Economic Policy, 23(4).

Matusiak K.B., 2011, Strategiczne obszary rozwoju parków technologicznych, Polska Agencja Rozwoju Przedsiębiorczości, Warszawa.

Pelle D., Bober M., Lis M., 2008, Parki technologiczne jako instrument polityki wspierania innowacji dyfuzji wiedzy, Instytut Badań Strukturalnych, Warszawa.

Staszków M., 2013, Parki naukowo-technologiczne - miejsce wsparcia innowacyjnego biznesu, Prace Naukowe Uniwersytetu Ekonomicznego we Wrocławiu, nr 315, vol. 2, s. 269-277.

Staszków M., 2016, How to measure tenants satisfaction in science and technology parks? Case study of office rental services in Polish STP, Studia Oeconomica Posnaniensia, 6, s. 115-128.

The World Bank, 2010, Innovation Policy. A Guide for Developing Countries, The International Bank for Reconstruction and Development, Washington D.C. 